\title{
Influence of Foliar Application of Water Soluble Fertilizers on Growth, Yield and Quality Attributes of Garlic (Allium sativum L.) var. Gujarat Garlic-3 in Southern Gujarat (India)
}

\author{
V.S. Mehta ${ }^{1}$, B.V. Padhiar ${ }^{1}$ and Vikas Kumar ${ }^{2 *}$ \\ ${ }^{1}$ Department of Plantation, Spices, Medicinal and Aromatic Crops, ASPEE College of \\ Horticulture and Forestry, Navsari Agricultural University, Navsari- 396450, Gujarat, India \\ ${ }^{2}$ Department of Silviculture and Agroforestry, College of Forestry, Vellanikkara, Kerala \\ Agricultural University, Thrissur, Kerala- 680656, Karnataka, India \\ *Corresponding author
}

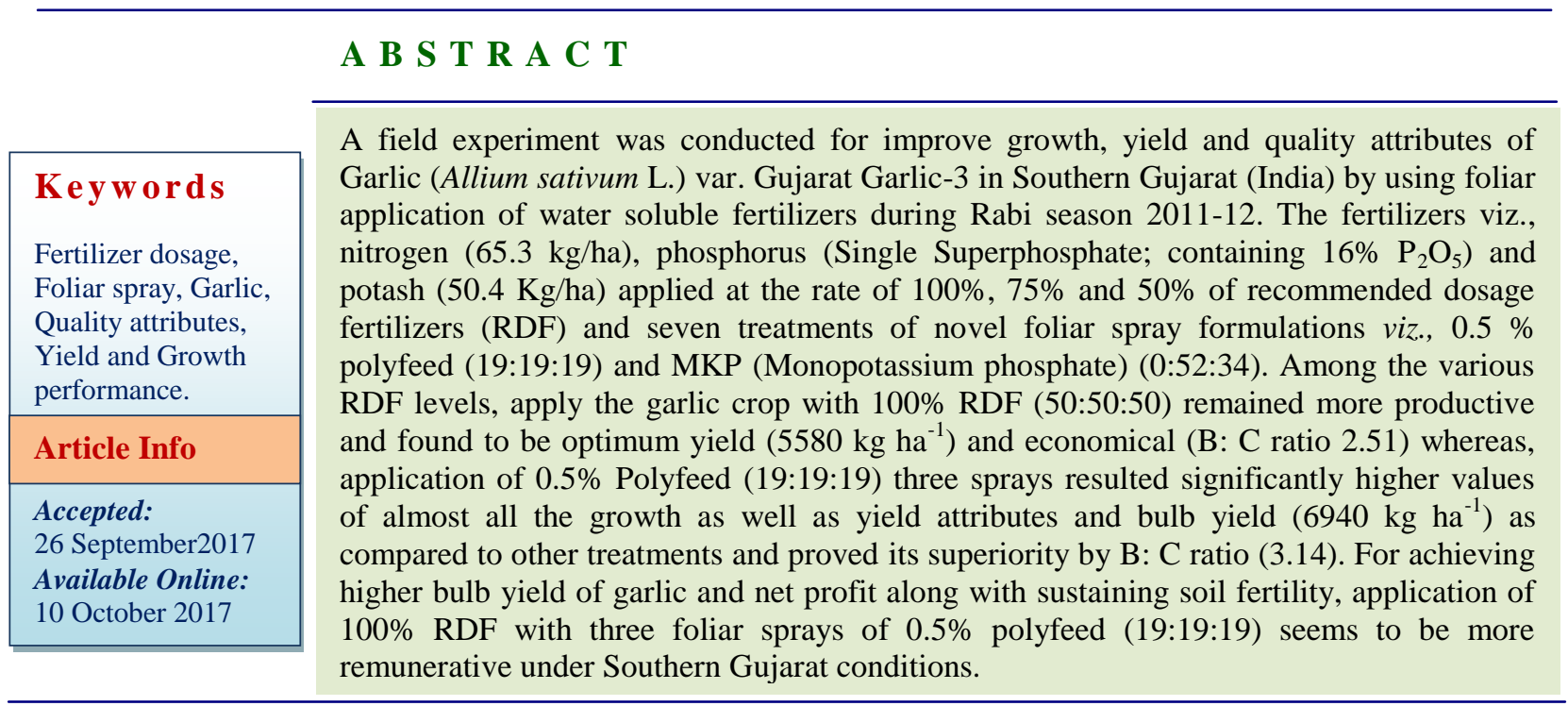

\section{Introduction}

Garlic (Allium sativum L.) belongs to the Alliaceae family and genus Allium, which contains more than 600 species, shallow rooted vegetable crop, and has been widely cultivated for more than 3000 years. It is commonly known as 'Lahsun', it is susceptible to numerous diseases caused by fungi, viruses, nematodes, insect pests and its with chromosome number $2 \mathrm{n}=16$ widely consumed crops in the world after onion (Sterlin and Eagling, 2001; Ovesná et al., 2011).
Garlic is used as a spices, seasonings, condiments, medicinal value as well as flavoring for foodstuff involving both green tops and bulbs (Dufoo-Hurtado et al., 2015). There are around 300 recognised and commercially cultivated varieties, but a large number of important varieties are undocumented on a small scale (Ovesná et al., 2011).

Since garlic plays an important role in human health, the quality of the nutritional 
components of this major bulbous crop is of particular concerns to producers throughout the world. Increase in demand of garlic obviated the necessity to increase its production, for which maximization of the bulb yield per unit area is rather a more desirable proposition than increasing the area under cultivation. Garlic cultivation has assured interest among the farmers of Gujarat (Bhavnagar, Junagadh, Rajkot, Jamnagar, Amreli and Navsari district) and other parts of the country because of its steadily increasing demand in the market at an attractive rate (Patel et al., 2017).

Plant growth and productivity is adversely affected by various biotic and abiotic factors, nutrients are one of the major abiotic factors, which adversely affects crop growth and yield. In this context, for producing crops with top quality and high yields especially on soils that is cultivated continuously. Garlic is more responsive to fertilizer application as well as method of nutrient application plays an vital role in supplying the nutrient to the plants, because the efficacy of fertilizer applied in the soil is very low due to the varies fixation and immobilization. The foliar application of urea was found effective only when these were supplemented with the soil application (Dhuria and Shukla, 1972). Nowadays application of N, P and K in different ratio through foliar spray is modern method of fertilization in agriculture/ horticulture crops due to nature of heavy feeder of nutrients. In this paper, we attempt to assess the different dosages of foliar application of water soluble fertilizers on growth, yield and quality attributes of garlic var. GG-3 performance under heavy black soil, Southern Gujarat condition.

\section{Materials and Methods}

The experiment was conducted at the RHRS farm $\left(20^{\circ} 57^{\prime} \mathrm{N}\right.$ latitude, $72^{\circ} 54^{\prime} \mathrm{E}$ longitude and an altitude of about $10 \mathrm{~m}$ above the mean sea level), ASPEE Collage of Horticulture and Forestry, Navsari Agricultural University, Navsari, Gujarat during the year 2011-12. The experimental system consisted of a randomized block design, with a factorial concept replicated three times, with total of 21 treatment combinations comprising three levels of inorganic fertilizers (RDF) and seven water soluble fertilizer regimes $(0.5 \%$ Polyfeed and $0.5 \%$ MKP) (Figure 1). The mean maximum and minimum temperature varies from $10.9^{\circ} \mathrm{C}$ to $35.7^{\circ} \mathrm{C}$. The physicochemical properties of irrigation water has mentioned in Table 1. The experiment plot was thoroughly prepared by ploughing and harrowing before sowing of garlic cloves and applied required quantity of recommended dose of FYM is 20 t/ha under South Gujarat conditions.

Inorganic Fertilizers viz., nitrogen (65.3 $\mathrm{kg} / \mathrm{ha}$ ), phosphorus (Single Superphosphate; containing $\left.16 \% \quad \mathrm{P}_{2} \mathrm{O}_{5}\right)$ and potash (50.4 $\mathrm{Kg} / \mathrm{ha}$ ) applied at the rate of $100 \%, 75 \%$ and $50 \%$ of recommended dose of fertilizers (RDF). FYM (20 t/ha) as well as inorganic fertilizers (50-50-50 kg NPK/ha).

Water Soluble Fertilizer viz., Polyfeed (19:19:19) and Mono Potassium Phosphate MKP (Mono Potassium Photsphate) (0:52:34) was applied as a foliar spray with $5 \mathrm{gm} / \mathrm{lit}$ $(0.5 \%)$ of dosage with an interval of 30,45 and 70 days after sowing with single, double or three sprays according to treatment allocation in the respective plots. APSA-80 was added along with water soluble fertilizers at a rate of $1 \mathrm{ml} /$ lit as an adhering agent to enhance the availability of nutrients.

\section{Plant material}

Garlic var. Gujarat Garlic-3 (GG-3) was collected from Vegetable Research Station, Junagadh Agricultural University (Erstwhile 
Gujarat Agricultural University, Junagadh). It is characterized by thick foliage; matures (135-140 days); diameter of bulb $(4-6 \mathrm{~cm})$ having cloves (20-22) and TSS (35-37\%).

\section{Seed sowing}

The quantity of required clove $(550 \mathrm{~kg} / \mathrm{ha})$ for experimental area was worked out. Presowing treatment with carbendazim $50 \%$ WP had done to check any fungal infections.

Ten plants were selected randomly from each net plot and tagged for recording observations on all the growth and yield attributing parameters from all the three replications. For recording different observations like growth and yield, ten plants of garlic from each net plot area were selected randomly in the beginning and tagged with the labels.

The garlic cloves contain essential oil which consists of allyl propyl disulfide and diallyl sulphide. For extraction of sulphide content, 10-20 g garlic cloves from each treatment were crushed and kept covered with $50 \mathrm{ml}$ of $70 \%$ methanol for $30 \mathrm{~min}$ at room temperature with occasional shaking. The methanol extract was filtered and concentrated by distilling most of the methanol. The concentrated extract was taken in a beaker, $5 \mathrm{ml}$ of $2 \mathrm{~N}$ HCL added and heated in water bath to dryness. The dry residue was extracted with solvent ether and the ether extract was concentrated and spotted on silica gel plates. The plates were developed in toluene-ethyl acetate (100:30). The chromatographs were dried at room temperature and sprayed with developed in two reagents $e . g$. vallinin-glacial acid reagent and palladium-II-chloride reagent. Sulphide compounds became visible as brown and orange spots at different height $(\mathrm{cm})$ which were compared with standard $\mathrm{R}_{\mathrm{f}}$ (Harborne, 1983; Daniel, 1992).

$\mathrm{Rf}=\frac{\text { Distance travelled by solute }(\mathrm{cm})}{\text { Distance travelled by solvent }(\mathrm{cm})}$

\section{Economics}

The gross realization in terms of rupees per hectare was calculated from the garlic yield at the prevailing market price. The cost of cultivation for each treatment was worked out by taking into consideration the cost of all the operations right from preparatory tillage to harvesting including cleaning as well as the cost of inputs viz., cloves, organic and inorganic fertilizers, irrigation, plant protection etc. The net realization was worked out by subtracting the total cost of cultivation from gross realization for each treatment and recorded in rupees per hectare.

\section{Statistical analysis}

The statistical analysis of the data on various growth and yield characters studied in the investigation was carried out through the statistical analysis of variance techniques as described by Panse and Sukhatme (1967). The method of analysis of variance for factorial randomized block design was used and treatment effects on all the characters studied were further compared by employing ' $\mathrm{F}$ ' test.

Five per cent level of significance was used to test the significance of the results. Summary tables for treatment effects have been prepared and presented with standard error of mean (S.Em. \pm ). The critical difference (C. D.) at 5 per cent level of significance was given for those treatments, which were found significant. The co-efficient of variance (C.V. $\%$ ) was also worked out.

\section{Results and Discussion}

\section{Vegetative growth parameters}

Application of foliar application of water soluble fertilizers didn't significantly affect the growth of garlic on number of leaves per plant and plant height (Table 2). 


\section{Number of leaves per plant}

The results presented in Table 2 showed the trend observed in the number of leaves produced by the plants at different stages of growth. The number of leaves increase across the treatments at all stages of growth. But, at all days (30, 60 and 90 days after planting), there were significant differences in the number of leaves per plant among the treatments.

The significantly maximum number of leaves and maximum height at 30, 60, 90 DAS, harvest time $(3.02,4.64,6.05$ and 11.71) and minimum days to maturity ( 124.40 days) were noted in $100 \%$ RDF whereas minimum observed in 50\% RDF. But, in foliar sprays Polyfeed (19:19:19) three sprays (30, 45 and 70 days) were maximum recorded number of leaves as well as plant height and the minimum days to maturity (123 days) whereas, least observed in all the vegetative parameters except minimum days to maturity (132.15) in Polyfeed (19:19:19) single spray (30days) (Table 2). This may be due to the effect of nitrogen is one of the major and indispensable constituents of protein and nucleic acid molecules, which ultimately trigger the rate of photosynthesis (Sharma et al., 2008; Pooja Rani et al., 2015). Similar trend was found by Das and Mohanty (2003) in garlic, Waghachavare (2004) and Shaheen et al., (2007) in onion with application of $50 \%$ RDF + 50\% FYM. Similar trend was observed by Shankar et al., (2002) in Onion by foliar application of sea weed extracts. The increase in growth parameters (plant height and number of leaves) with an increase in water soluble fertilizer levels might be due to the increased cell division and elongation at higher level of N. Higher levels of N and P at early crop stage could have encouraged more number of axillary buds and ultimately resulted in more number of branches in tomato as observed by Chaurasia et al.,
(2006). In context of minimum day to maturity, the hormones and organic acid secreted by organic manures along with RDF may be possible reason that leads to early maturity. Present results are supported by the findings of Birajadar (1991) and Waghachavare (2004) in onion. Similar findings were also found by Jaafari and Hadavi (2012) in Basil and Maleki et al., (2013) in Sweet Basil.

\section{Yield and yield parameters}

All the important attributes related to bulb characteristics and bulb yield were significantly by the fertilizer dosages and foliar application of water soluble fertilizers (Table 3). The result indicated that significantly maximum fresh weight $(26.26 \mathrm{~g})$ and dry weight $(17.50 \mathrm{~g})$ of bulb, bulb diameter $(3.62 \mathrm{~cm})$, number of cloves per bulb (18.53), clove length $(2.09 \mathrm{~cm})$ and clove weight $(1.04 \mathrm{~g})$ were recorded when the garlic crop treated with $100 \%$ RDF $\left(D_{1}\right)$ (Table 3). It showed that the bulb diameter gradually decreased with subsequent decrease in dose of fertilizers. Consequently, the foliar sprays Polyfeed (19:19:19) three sprays (30, 45 and 70 days) were the maximum fresh weight $(29.20 \mathrm{~g})$ and dry weight $(18.23 \mathrm{~g})$ of bulb, bulb diameter $(4.25 \mathrm{~cm})$, number of cloves per bulb (19.80), clove length (2.56 $\mathrm{cm})$ and clove weight $(1.80 \mathrm{~g})$ and least observed in treated with foliar sprays Polyfeed (19:19:19) single sprays (30 days) (Table 3) (Figure 1). The increase in yield attributing characters only due to the balanced fertilizer application is essential for the vegetative growth and improved management of N, P, K and other nutrients in the soil could improve yields and quality of attributes crops (Nai-hua et al., 1998). Similar response with foliar spray of thiourea was also recorded by Balai and Keshwa (2011), Shanu et al., (2013) in coriander and Gupta and Yadav (2009) in fenugreek. Foliar spray of citric acid 
could result in stimulation or increase in proton pump activity in roots. This stimulatory effect may be also occurring with foliar application and transferred to root and resulting an increase in organic acid and protons efflux. This can increase the uptake of ions such as nitrogen and phosphorus by plants, which ultimately enhance yield and yield attributes (Maleki et al., 2013). The obtained result is good agreement with the result of Jaafari and Hadavi (2012).

The maximum yield $(2.79 \mathrm{~kg} / \mathrm{plot})$ and total yield $(5580 \mathrm{~kg} / \mathrm{ha})$ of garlic were significant influenced by treated with $100 \% \operatorname{RDF}\left(\mathrm{D}_{1}\right)$ (Table 3) and the foliar sprays Polyfeed (19:19:19) three sprays (30, 45 and 70 days) were the maximum yield $(3.48 \mathrm{~kg} / \mathrm{plot})$ and total yield $(6960 \mathrm{~kg} / \mathrm{ha})$ of garlic. It might be due to the fact that application of recommended dose of NPK have accelerated the synthesis of chlorophyll associated with photosynthesis and accumulated carbohydrates that resulted an increase in the size of bulb as indicated by diameter and average bulb weight, and ultimately the overall yield. Similar finding were also noticed by Kolota and Osinska (2001) in cabbage, Batra et al., (2002) in brinjal, Warade et al., (2004) in onion, Talware et al., (2010) in Garlic, Haldar et al., (2012) in coriander which were in conformity of the present investigation.

The probable reasons for higher bulb weight, bulb diameter, number of cloves per bulb, clove length and weight under higher frequency of water soluble fertilizer (Polyfeed - 19:19:19) over lower frequency might be due to adequate availability of easily soluble nutrients. This attribute to an optimum level of synthesis of cytokinins at higher levels of $\mathrm{N}$ and $\mathrm{P}$ would have resulted in a favourable sink to supply more nutrients during critical growth stages. Increase in availability of $\mathrm{N}$ from foliar spray fastens the photosynthetic activity. Increase in bulb growth was attributed to the better utilization of photosynthates and increased allocation of photosynthates towards the economically useful parts. These findings are in conformity with the results of Narayanamma et al., (2006) in brinjal, Yildirim et al., (2007) in broccoli, Chakraborty and Chaudhuri (2008) in garlic and Premsekhar and Rajashree (2009) in tomato.

Table.1 Quality of irrigation water used in experiment

\begin{tabular}{|l|l|l|l|l|c|}
\hline Sr No. & Constituents & Value & Sr No. & Constituents & Value \\
\hline 1. & $\mathrm{pH}$ & 7.38 & 6. & Sodium Adsorption Ratio (SAR) & 1.18 \\
\hline 2. & EC $\left(\mathrm{dSm}^{-1}\right.$ at $\left.25^{\circ} \mathrm{C}\right)$ & 1.06 & 7. & Carbonate (me/l) & 0.30 \\
\hline 3. & Calcium (me/l) & 2.89 & 8. & Bicarbonate (me/l) & 5.79 \\
\hline 4. & Magnesium (me/l) & 2.22 & 9. & Chlorides (me/l) & 0.82 \\
\hline 5. & Sodium (me/l) & 1.90 & 10. & $\begin{array}{l}\text { Residual Sodium Carbonate } \\
(\text { RSC) }(\mathrm{me} / \mathrm{l})\end{array}$ & 0.95 \\
\hline
\end{tabular}


Table.2 Effect of foliar application of water soluble fertilizers on growth parameters of garlic var. GG-3

\begin{tabular}{|c|c|c|c|c|c|c|c|c|c|}
\hline \multirow[t]{2}{*}{ Treatments } & \multicolumn{4}{|c|}{ No. of leaves per plant } & \multicolumn{4}{|c|}{ Plant height $(\mathbf{c m})$} & \multirow{2}{*}{$\begin{array}{c}\text { Mean } \\
\text { maturity } \\
\text { days }\end{array}$} \\
\hline & $\begin{array}{c}\text { 30 } \\
\text { DAS }\end{array}$ & $\begin{array}{c}\text { 60 } \\
\text { DAS }\end{array}$ & $\begin{array}{c}90 \\
\text { DAS }\end{array}$ & $\begin{array}{c}\text { After } \\
\text { Harvest }\end{array}$ & $\begin{array}{c}\text { 30 } \\
\text { DAS }\end{array}$ & $\begin{array}{c}\text { 60 } \\
\text { DAS }\end{array}$ & $\begin{array}{c}\text { 90 } \\
\text { DAS }\end{array}$ & $\begin{array}{c}\text { After } \\
\text { Harvest }\end{array}$ & \\
\hline \multicolumn{10}{|l|}{ A. Recommended dose of fertilizers (D) } \\
\hline $\mathrm{D}_{2}: 75 \%$ RDF (37.5:37.5:37.5) & 2.91 & 4.61 & 5.94 & 11.01 & 25.57 & 36.52 & 39.43 & 43.53 & 129.15 \\
\hline $\mathrm{D}_{3}: 50 \%$ RDF $(25: 25: 25)$ & 2.76 & 4.48 & $5.78 \mathrm{r}$ & 10.35 & 24.60 & 34.50 & 36.12 & 40.56 & 133.64 \\
\hline \multicolumn{10}{|l|}{ B. Water soluble fertilizers (T) } \\
\hline $\begin{array}{l}\mathrm{T}_{1} \text { : Polyfeed (19:19:19) Single spray } \\
{[30 \mathrm{DAS}]}\end{array}$ & 2.94 & 4.70 & 6.53 & 10.84 & 26.40 & 37.84 & 40.34 & 44.56 & 132.15 \\
\hline $\begin{array}{l}\mathrm{T}_{2}: \text { Polyfeed (19:19:19) Two sprays } \\
{[30 \text { and } 45 \text { DAS] }}\end{array}$ & 2.98 & 4.72 & 6.71 & 11.88 & 26.55 & 38.92 & 41.33 & 45.93 & 131.70 \\
\hline $\begin{array}{l}\mathrm{T}_{5}: \text { MKP }(0: 52: 34) \text { Two sprays } \\
{[30 \text { and } 45 \text { DAS] }}\end{array}$ & 2.83 & 4.49 & 5.75 & 11.07 & 26.48 & 37.56 & 39.56 & 43.78 & 133.00 \\
\hline $\mathrm{T}_{6}:$ MKP $(0: 52: 34)$ Three sprays & 2.90 & 4.45 & 5.75 & 11.44 & 26.50 & 37.68 & 40.56 & 44.52 & 131.12 \\
\hline $\mathrm{T}_{7}$ : Control (No spray) & 1.98 & 3.51 & 4.02 & 9.63 & 24.52 & 35.68 & 37.76 & 39.34 & 138.67 \\
\hline S.Em. \pm & 0.03 & 0.07 & 0.10 & 0.27 & 0.63 & 0.82 & 1.03 & 1.30 & 2.44 \\
\hline C.D. @ 5\% & 0.11 & 0.23 & 0.29 & 0.78 & NS & NS & 2.27 & 2.73 & 7.65 \\
\hline \multicolumn{10}{|l|}{ C. Interaction } \\
\hline $\mathrm{DX} \mathrm{T}$ & NS & NS & NS & NS & NS & NS & NS & NS & NS \\
\hline C.V. \% & 8.06 & 6.32 & 4.29 & 5.46 & 7.91 & 6.18 & 6.34 & 7.82 & 10.58 \\
\hline
\end{tabular}

DAS: Days after sowing; NS: Nonsignificant 
Table.3 Effect of foliar application of water soluble fertilizers on yield parameter of garlic var. GG-3

\begin{tabular}{|c|c|c|c|c|c|c|c|c|}
\hline Treatments & $\begin{array}{c}\text { Diameter } \\
\text { of bulb } \\
(\mathbf{c m})\end{array}$ & $\begin{array}{c}\text { Fresh } \\
\text { weight of } \\
\text { bulb }(\mathrm{g}) \\
\end{array}$ & $\begin{array}{c}\text { Cured } \\
\text { weight of } \\
\text { bulb (g) } \\
\end{array}$ & $\begin{array}{c}\text { No. of } \\
\text { cloves } \\
\text { per bulb }\end{array}$ & $\begin{array}{c}\text { Clove } \\
\text { length } \\
(\mathrm{cm}) \\
\end{array}$ & $\begin{array}{c}\text { Clove } \\
\text { weight } \\
\text { (g) }\end{array}$ & $\begin{array}{c}\text { Bulb } \\
\text { Yield } \\
\left(\mathrm{kg} \mathrm{plot}^{-1}\right)\end{array}$ & $\begin{array}{c}\text { Bulb Yield } \\
\left(\mathrm{kg} \mathrm{ha}^{-1}\right)\end{array}$ \\
\hline \multicolumn{9}{|l|}{ A. Recommended dose of fertilizers (D) } \\
\hline $\mathrm{D}_{1}: 100 \%$ RDF $(50: 50: 50)$ & 3.62 & 26.26 & 17.50 & 18.53 & 2.09 & 1.04 & 2.79 & 5580 \\
\hline $\mathrm{D}_{2}: 75 \%$ RDF $(37.5: 37.5: 37.5)$ & 3.59 & 24.53 & 16.45 & 17.65 & 1.94 & 1.08 & 2.63 & 5260 \\
\hline $\mathrm{D}_{3}: 50 \%$ RDF $(25: 25: 25)$ & 3.35 & 23.03 & 15.25 & 16.83 & 1.59 & 0.97 & 1.75 & 3500 \\
\hline S.Em. \pm & 0.76 & 0.64 & 0.43 & 0.34 & 0.03 & 0.02 & 0.06 & 138.87 \\
\hline C.D. @ 5\% & 0.19 & 1.83 & 1.23 & 0.98 & 0.16 & 0.05 & 0.18 & 392.76 \\
\hline \multicolumn{9}{|l|}{ B. Water soluble fertilizers ( $\mathrm{T}$ ) } \\
\hline $\begin{array}{l}\mathrm{T}_{1}: \text { Polyfeed (19:19:19) Single spray } \\
{[30 \mathrm{DAS}]}\end{array}$ & 3.98 & 22.78 & 15.89 & 17.98 & 1.93 & 1.43 & 2.98 & 5960 \\
\hline $\begin{array}{l}\mathrm{T}_{2}: \text { Polyfeed (19:19:19) Two sprays } \\
\text { [30 and 45 DAS] }\end{array}$ & 4.17 & 26.78 & 16.99 & 18.67 & 2.34 & 1.74 & 3.32 & 6640 \\
\hline $\begin{array}{l}\mathrm{T}_{3}: \text { Polyfeed (19:19:19) Three sprays } \\
{[30,45 \text { and } 70 \text { DAS }]}\end{array}$ & 4.25 & 29.20 & 18.23 & 19.80 & 2.56 & 1.80 & 3.48 & 6960 \\
\hline $\begin{array}{l}\mathrm{T}_{4}: \mathrm{MKP}(0: 52: 34) \text { Single spray } \\
{[30 \mathrm{DAS}]}\end{array}$ & 3.89 & 24.78 & 16.08 & 17.57 & 1.80 & 0.96 & 2.67 & 5940 \\
\hline $\begin{array}{l}\mathrm{T}_{5}: \text { MKP }(0: 52: 34) \text { Two sprays } \\
{[30 \text { and } 45 \text { DAS }]}\end{array}$ & 3.98 & 24.80 & 16.30 & 18.13 & 1.93 & 1.09 & 3.07 & 6140 \\
\hline $\begin{array}{l}\mathrm{T}_{6}: \mathrm{MKP}(0: 52: 34) \text { Three sprays } \\
{[30,45 \text { and } 70 \mathrm{DAS}]}\end{array}$ & 4.05 & 25.70 & 16.74 & 18.25 & 2.16 & 1.26 & 3.10 & 6200 \\
\hline $\mathrm{T}_{7}:$ Control (No spray) & 3.12 & 16.40 & 14.44 & 15.85 & 1.34 & 0.70 & 2.46 & 4960 \\
\hline S.Em. \pm & 0.81 & 0.98 & 0.66 & 0.52 & 0.05 & 0.03 & 0.09 & 134.73 \\
\hline C.D. @ 5\% & 0.23 & 2.80 & 1.88 & 1.50 & 0.36 & 0.08 & 0.27 & 386.52 \\
\hline \multicolumn{9}{|l|}{ C. Interaction } \\
\hline $\mathrm{DX} \mathrm{T}$ & NS & NS & NS & NS & $\mathrm{NS}$ & $\mathrm{NS}$ & NS & NS \\
\hline C.V. \% & 9.91 & 12.07 & 12.09 & 9.42 & 9.04 & 9.12 & 14.77 & 11.28 \\
\hline
\end{tabular}


Table.4 Effect of foliar application of water soluble fertilizers on quality parameter of garlic var. GG-3

\begin{tabular}{|c|c|c|}
\hline Treatments & Total Soluble Solids (TSS) (\%) & Protein \% \\
\hline \multicolumn{3}{|l|}{ A. Recommended dose of fertilizers (D) } \\
\hline $\mathrm{D}_{1}: 100 \% \mathrm{RDF}(50: 50: 50)$ & 36.10 & 26.6 \\
\hline $\mathrm{D}_{2}: 75 \%$ RDF $(37.5: 37.5: 37.5)$ & 35.46 & 26.2 \\
\hline $\mathrm{D}_{3}: 50 \%$ RDF $(25: 25: 25)$ & 33.09 & 25.8 \\
\hline S.Em. \pm & 0.64 & 0.27 \\
\hline C.D. @ 5\% & 1.83 & NS \\
\hline \multicolumn{3}{|l|}{ B. Water soluble fertilizers (T) } \\
\hline $\begin{array}{l}\mathrm{T}_{1}: \text { Polyfeed (19:19:19) Single spray } \\
{[30 \mathrm{DAS}]}\end{array}$ & 35.44 & 26.6 \\
\hline $\begin{array}{l}\mathrm{T}_{2}: \text { Polyfeed (19:19:19) Two sprays } \\
{[30 \text { and } 45 \mathrm{DAS}]}\end{array}$ & 36.74 & 26.6 \\
\hline $\begin{array}{l}\mathrm{T}_{3}: \text { Polyfeed (19:19:19) Three sprays }[30,45 \\
\text { and } 70 \text { DAS] }\end{array}$ & 37.94 & 27.2 \\
\hline $\begin{array}{l}\mathrm{T}_{4}: \text { MKP }(0: 52: 34) \text { Single spray } \\
{[30 \mathrm{DAS}]}\end{array}$ & 36.16 & 26.4 \\
\hline $\begin{array}{l}\mathrm{T}_{5}: \text { MKP }(0: 52: 34) \text { Two sprays } \\
{[30 \text { and } 45 \text { DAS] }}\end{array}$ & 34.53 & 26.6 \\
\hline $\begin{array}{l}\mathrm{T}_{6}: \text { MKP }(0: 52: 34) \text { Three sprays } \\
{[30,45 \text { and } 70 \text { DAS }]}\end{array}$ & 35.92 & 26.6 \\
\hline $\mathrm{T}_{7}:$ Control (No spray) & 34.73 & 24.9 \\
\hline S.Em. \pm & 0.98 & 0.28 \\
\hline C.D. @ 5\% & 1.10 & NS \\
\hline \multicolumn{3}{|l|}{ C. Interaction } \\
\hline $\mathrm{D} X \mathrm{~T}$ & NS & NS \\
\hline C.V. \% & 6.44 & 5.68 \\
\hline
\end{tabular}


Table.5 Effect of foliar application of water soluble fertilizers on sulphides content of garlic var. GG-3

\begin{tabular}{|c|c|c|c|c|c|c|c|c|}
\hline \multirow[b]{2}{*}{ Treatments } & \multicolumn{2}{|c|}{ Diallyl sulfide } & \multicolumn{2}{|c|}{ Allicin } & \multicolumn{2}{|c|}{ Diprophylthiosulphinate } & \multicolumn{2}{|c|}{ Dimethylthiosulphinate } \\
\hline & $\begin{array}{c}\text { Standard } \\
\text { Rf }\end{array}$ & $\begin{array}{c}\text { Obtained } \\
\text { Rf }\end{array}$ & $\begin{array}{c}\text { Standard } \\
\text { Rf }\end{array}$ & $\begin{array}{c}\text { Obtained } \\
\text { Rf }\end{array}$ & $\begin{array}{c}\text { Standard } \\
\text { Rf }\end{array}$ & $\begin{array}{c}\text { Obtained } \\
\text { Rf }\end{array}$ & $\begin{array}{c}\text { Standard } \\
\text { Rf }\end{array}$ & $\begin{array}{c}\text { Obtained } \\
\text { Rf }\end{array}$ \\
\hline \multicolumn{9}{|l|}{ A. Recommended dose of fertilizers (D) } \\
\hline $\mathrm{D}_{1}: 100 \%$ RDF (50:50:50) & 0.05 & 0.05 & 0.45 & 0.44 & 0.45 & 0.36 & 0.30 & 0.19 \\
\hline $\mathrm{D}_{2}: 75 \% \operatorname{RDF}(37.5: 37.5: 37.5)$ & 0.05 & 0.05 & 0.45 & 0.40 & 0.45 & 0.30 & 0.30 & 0.17 \\
\hline $\mathrm{D}_{3}: 50 \%$ RDF $(25: 25: 25)$ & 0.05 & 0.05 & 0.45 & 0.35 & 0.45 & 0.26 & 0.30 & 0.15 \\
\hline S.Em. \pm & & 0.005 & & 0.025 & & 0.017 & & 0.07 \\
\hline C.D. @ 5\% & & NS & & NS & & NS & & NS \\
\hline \multicolumn{9}{|l|}{ B. Water soluble fertilizers $(\mathrm{T})$} \\
\hline $\mathrm{T}_{1}$ : Polyfeed (19:19:19) Single spray & 0.05 & 0.04 & 0.45 & 0.43 & 0.45 & 0.31 & 0.30 & 0.15 \\
\hline $\mathrm{T}_{2}$ : Polyfeed (19:19:19) Two sprays & 0.05 & 0.05 & 0.45 & 0.45 & 0.45 & 0.35 & 0.30 & 0.17 \\
\hline $\mathrm{T}_{3}:$ Polyfeed (19:19:19) Three sprays & 0.05 & 0.06 & 0.45 & 0.45 & 0.45 & 0.40 & 0.30 & 0.19 \\
\hline $\mathrm{T}_{4}: \mathrm{MKP}(0: 52: 34)$ Single spray & 0.05 & 0.05 & 0.45 & 0.44 & 0.45 & 0.34 & 0.30 & 0.15 \\
\hline $\mathrm{T}_{5}: \mathrm{MKP}(0: 52: 34)$ Two sprays & 0.05 & 0.04 & 0.45 & 0.44 & 0.45 & 0.34 & 0.30 & 0.17 \\
\hline $\mathrm{T}_{6}: \mathrm{MKP}(0: 52: 34)$ Three sprays & 0.05 & 0.05 & 0.45 & 0.45 & 0.45 & 0.35 & 0.30 & 0.17 \\
\hline $\mathrm{T}_{7}$ : Control (No spray) & 0.05 & 0.04 & 0.45 & 0.43 & 0.45 & 0.30 & 0.30 & 0.15 \\
\hline S.Em. \pm & & 0.004 & & 0.027 & & 0.019 & & 0.09 \\
\hline C.D.@ $9 \%$ & & NS & & NS & & NS & & NS \\
\hline \multicolumn{9}{|l|}{ C. Interaction } \\
\hline $\mathrm{DX} \mathrm{T}$ & & NS & & NS & & NS & & NS \\
\hline C.V. $\%$ & & 11.06 & & 11.37 & & 9.07 & & 8.82 \\
\hline
\end{tabular}


Table.6 Effect of foliar application of water soluble fertilizers on economics content of garlic var. GG-3

\begin{tabular}{|c|c|c|c|c|c|c|c|}
\hline Treatments & $\begin{array}{c}\text { Marketable } \\
\text { yield } \\
\left(\mathbf{k g ~ h a}^{-1}\right)\end{array}$ & $\begin{array}{c}\text { Treatment } \\
\text { cost } \\
\left(\text { Rs. ha } \mathbf{~ h}^{-1}\right)\end{array}$ & $\begin{array}{c}\text { Operational } \\
\text { cost } \\
\left(\text { Rs. } \text { ha }^{-1}\right)\end{array}$ & \begin{tabular}{|c|}
$\begin{array}{c}\text { Total cost of } \\
\text { cultivation } \\
(\text { Rs. ha }\end{array}$-1 $\left.^{-1}\right)$ \\
$($ No. $2+$ No. 3)
\end{tabular} & $\begin{array}{c}\text { Gross return } \\
(\text { Rs. ha-1 }) \\
\text { (No. } 1 \text { x Rs. 30) }\end{array}$ & $\begin{array}{c}\text { Net return } \\
(\text { Rs. ha-1) } \\
\text { (No. } 5 \text { - No. 4) }\end{array}$ & $\begin{array}{c}\text { Benefit : Cost } \\
\text { ratio (B:C) } \\
\text { (No. 6/No. 4) }\end{array}$ \\
\hline & 1 & 2 & 3 & 4 & 5 & 6 & 7 \\
\hline \multicolumn{8}{|c|}{ A. RDF Levels (D) } \\
\hline $\mathbf{D}_{1}$ & 5580 & 1307 & 46,250 & 47,557 & $1,67,400$ & $1,19,843$ & 2.51 \\
\hline $\mathbf{D}_{2}$ & 5260 & 990 & 46,250 & 47,240 & $1,57,800$ & $1,10,560$ & 2.34 \\
\hline $\mathbf{D}_{3}$ & 3500 & 675 & 46,250 & 46,925 & $1,05,000$ & 58,075 & 1.24 \\
\hline \multicolumn{8}{|c|}{ B. Water Soluble fertilizers (T) } \\
\hline $\mathbf{T}_{1}$ & 5960 & 384 & 47,250 & 47,634 & $1,78,800$ & $1,31,166$ & 2.75 \\
\hline $\mathbf{T}_{2}$ & 6640 & 768 & 48,250 & 49,018 & $1,99,200$ & $1,50,182$ & 3.06 \\
\hline $\mathbf{T}_{3}$ & 6960 & 1152 & 49,250 & 50,402 & $2,08,800$ & $1,58,398$ & 3.14 \\
\hline $\mathbf{T}_{4}$ & 5940 & 699 & 47,250 & 47,949 & $1,78,200$ & $1,30,251$ & 2.71 \\
\hline $\mathbf{T}_{5}$ & 6140 & 1398 & 48,250 & 49,648 & $1,84,200$ & $1,34,552$ & 2.71 \\
\hline $\mathbf{T}_{6}$ & 6200 & 2097 & 49,250 & 51,347 & $1,86,000$ & $1,34,653$ & 2.62 \\
\hline $\mathbf{T}_{7}$ & 4960 & 0 & 46,250 & 46,250 & $1,48,800$ & $1,02,550$ & 2.22 \\
\hline
\end{tabular}


Figure 1: A schematic presentation of the experimental representation: A. General view of experimental plot; B. Visual aids of treatments effects on bulb (I) and clove quality (II); C. Effect of RDF levels and water soluble fertilizers on bulb diameter and clove length (cm) of garlic var. GG-3; and D. Cromatograms of sulphide compounds: Vanillin-glacial acid regent (VGA-42) (I) and Palladium-II-chloride regent (PC-32) (II)
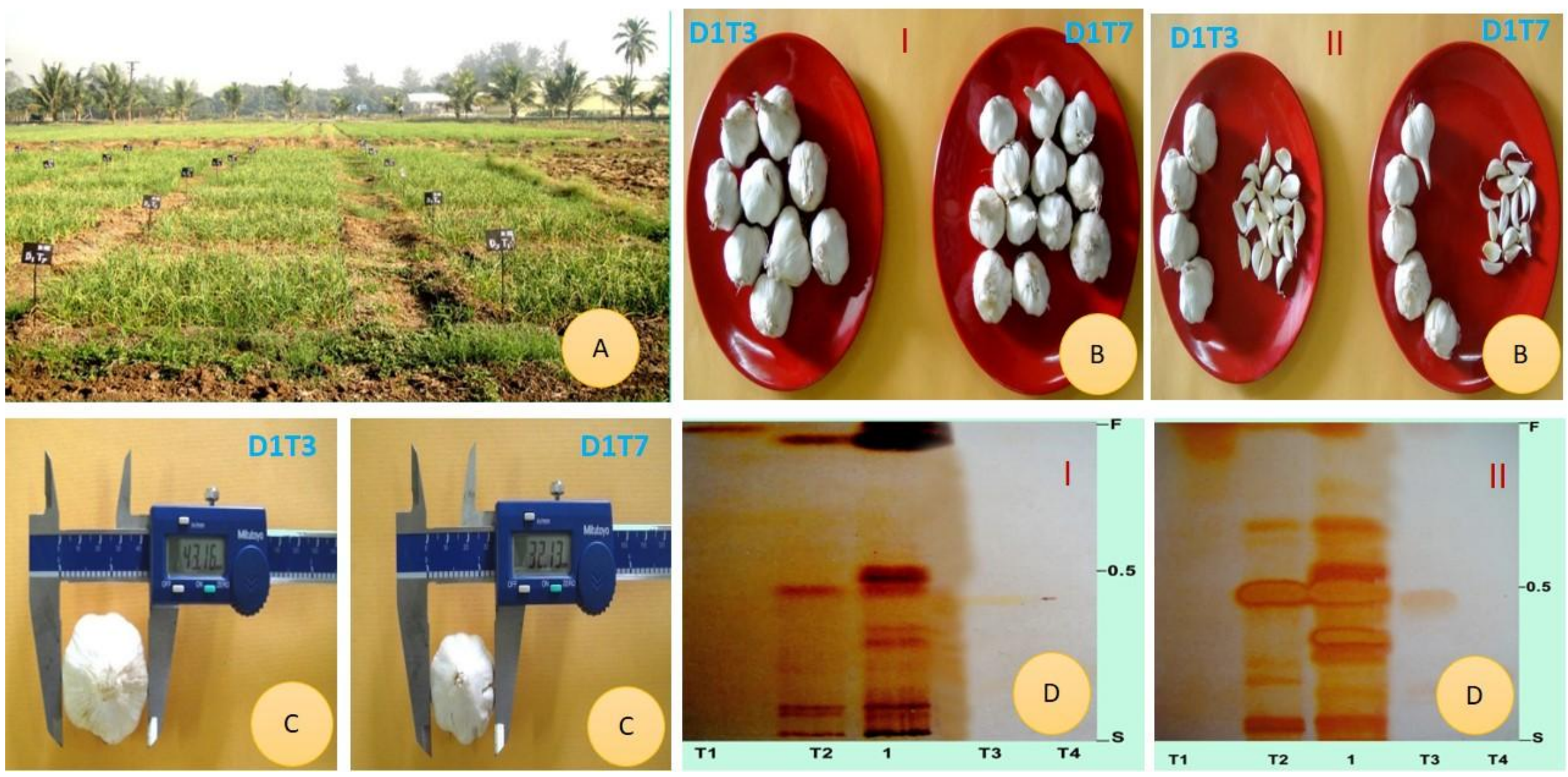


\section{Quality parameter}

\section{Total soluble solids (\%)}

The effect of different levels of RDF revealed total soluble solids (\%) in garlic were not affected significantly by this variable. Numerically, the higher TSS $(36.10 \%)$ was recorded in treatment $\mathrm{D}_{1}$ (Table 4). A comparison between high and low level of NPK revealed that these nutrients play major role in quality improvement through desirable enzymatic changes taking place during growth and ascribed to increase production of carbohydrates during photosynthesis. These results are consequences with the findings of Waghachavare (2004) in onion. The highest TSS $(37.94 \%)$ was found with the treatment $\mathrm{T}_{3}$ (Polyfeed - three sprays). On the contrary, the lowest TSS $(34.73 \%)$ was recorded with the treatment $\mathrm{T}_{7}$. The increase in TSS might be due to the growth promoting substances which could have accelerated the synthesis of carbohydrates, vitamins and other qualitative characters (Chaurasia et al., 2006). Similar results were revealed by Premsekhar and Rajashree (2009) in tomato.

\section{Protein content $(\%)$}

It inferred the highest protein content was registered $(26.6 \%)$ under the treatment $D_{1}$ $(100 \%$ RDF) and three sprays of polyfeed (Table 4). The findings were similar to one reported by Singh and Pandey (2006) in onion.

\section{Sulphides content}

RDF levels have not impacted significantly to the sulfide contents of garlic (Table 5). There was no differences found in $R_{f}$ values of four compound isolated (Figure 1). Diallyl sulfide content showed similar $R_{f}$ range in all the three treatments $\left(D_{1}, D_{2}\right.$ and $\left.D_{3}\right)$. No significant differences found in relation to effect of different water soluble fertilizer sprays on sulfide compounds. The isolated compounds were near to their standard $R_{f}$ range in all treatments. High sulphur content is particularly cherished in garlic because it provides a base for formation of alkyl alkenethiosulphinates, sulfenic acid and allicin which are the major pungency compounds in garlic (Watson, 2005; Cantwell et al., 2006). Allicin is a natural antibiotic, major constitute of garlic flavour and medicinal properties. However, nitrogen is responsible for the flavour and medicinal attributes of garlic. Nevertheless, Jones et al., (2004) had reported that sulphur metabolism is intimately related to Nitrogen metabolism through production of cysteine amino acid. Provision of adequate nitrogen (in form of soluble nitrogen through foliar application) would have affected as catalyst in this process and might accelerate the suphur content of garlic.

Extracts of fresh bulb samples of garlic var. GG-3 showed a similar qualitative pattern of four yellow brown zones thiosulphinate of in the $R_{f}$ range of $0.15-0.20$ in both factors which was lower as compared to Standard $R_{f}$ values. Allicin at $R_{f}$ range of 0.45 was the major compound found in both factors.

\section{Economics}

The economics indicating gross return in rupees per hectare was worked out from the bulb yield of garlic by taking in to account the prevailing market price at the time of harvest. It was explicated (Table 6) that maximum net return registered with $100 \%$ RDF (Rs 1, 19, $\left.843 \mathrm{ha}^{-1}\right)$. It indicated that the net return decreased with decease in availability of nutrients from $D_{1}$ to $D_{3}$. Among the water soluble fertilizer sprays, the highest net return was registered with three foliar sprays of Polyfeed $\left(\mathrm{T}_{3}\right)\left(\mathrm{Rs} 1,58,398 \mathrm{ha}^{1}\right)$, the highest B: C ratio (3.14) was observed with treatment 
$\mathrm{T}_{3}$. Due to low production of garlic var. GG-3 in South Gujarat an attempt was made to increase the production by supplementing recommended dose of NPK with foliar application of different dosages. In the present study treated with $100 \%$ RDF $\left(\mathrm{D}_{1}\right)$ and foliar sprays Polyfeed (19:19:19) three sprays (30, 45 and 70 days) increase growth and yield parameters and proved as a better treatment for garlic var. GG-3 in Southern Gujarat condition.

\section{References}

Balai, L.R. and Keshwa, G.L. 2011. Effect of thiourea on yield and nutrient uptake of coriander (Coriandrum sativum L.) varieties under normal and late shown conditions. Journal of Spices and Aromatic Crops. 20(1): 34-37.

Batra, V. K., Singh, B. and Singh, V. 2002. Response of brinjal to foliar feeding of water soluble fertilizers. Int. Conference on Vegetables, pp.11-14.

Birajdar, B.G. 1991. Effect of inorganic, organic and biofertilizers and their combination on growth, yield and storage of onion (Allium cepa L.) bulbs Cv.N-2-4-1. Journal of Indian Society of Soil Science. 78: 716-719.

Cantwell, M., Voss, R., Hanson, B., May, D. and Rice, B. 2006. Water and fertilizer management of garlic: Productivity, Nutrient and Water Use Efficiency, and Post-harvest Quality. Report of a FREP.

Chakraborty, P. and Chaudhuri, P. 2008. Effect of foliar application of gibberellic acid on growth, yield and quality parameters of garlic. Orissa Journal of Horticulture. 36 (2): 42-49.

Chaurasia, S.N.S., Singh, K.P. and Rai, M. 2006. Response of tomato to foliar application of water soluble fertilizers. Vegetable Science. 33 (1): 96-97.

Daniel, M. 1992. Methods in phytochemistry and economic botany. Kalyani Publishers, New Delhi.
Das, J.N. and Mohanty, B.K. 2003. Effect of plant density and mineral nutrition on the yield of garlic (Allium sativum) cv. Madrasi. Vegetable Science. 28 (1): 9293.

Dhuria, H.S. and Shukla, V. 1972. Foliar application of urea on tomato. Indian Journal of Horticulture. 30: 425-527.

Dufoo-Hurtado, M.D., Huerta-Ocampo, J.A., Barrera-Pacheco, A., Barba de la Rosa, A.P. and Mercado-Silva, E.M. 2015. Low temperature conditioning of garlic (Allium sativum L.) "seed" cloves induces alterations in sprouts proteome. Frontiers in Plant Science. 6:332.

Gupta, D.K. and Yadav, S.S. 2009. Response of fenugreek to varying levels of sulphur and bio-regulators. Published by S.K.N. College of Agriculture in National seminar on Spices and Aromatic plants in 21th century India. 67.

Haldar, A., Naruka, I.S., Singh, P.P. and Rathore, S.S. 2012. Effect of antioxidants on growth, yield and quality of garlic (Allium sativum L.). Medicinal Plants. 4(4): 206-211.

Harborne, J. 1983. Phytochemical Methods. Oxford and JBH Publishing House, New York.

Jaafari, N. and Hadavi, E. 2012. Growth and essential oil yield of Basil (Ocimum basilicum L.) as affected by foliar spray of citric acid and salicylic acid. Journal of Medicinal and Spices Plants. 17(2): 80-83.

Jones, G. M., Hughes, J., Tregova, A., Milne, J., Brian, A. and Collin, A. (2004). Biosynthesis of the Flavour Precursor of Onion and Garlic. Journal of Experimental Botany. 55 (404): 19031918.

Kolota, E. and Osinska, M. 2001. Efficiency of foliar nutrition of field vegetables grown at different nitrogen rates. In: Proc. IC Environ. Probl. N-Fert. Acta 
Horticulturae, 563: 87-91.

Maleki, V., Ardakani, M.R., Rejali, F. and Taherpour, A.A. 2013. Physiological response of Sweet basil to triple inoculation with azotobacter, azospirillum, glomus interaradices and foliar application of citric acid. Annals of Biological Research. 4(1):62-71.

Nai-hua, Y., Dingguo, Z. and Wang, J. 1998. Phosphorus and Potassium Nutrient Management for Vegetable Soils in Shanghai and Guangdong. In: Donald L. Armstrong (Ed.), Better Crops International, 12(1):1.

Narayanamma, M. C., Sai-Reddy, C., Chiranjeevi and Reddy, P. 2006. Influence of water soluble fertilizers on yield of brinjal. Vegetable Science. 33(2): 94-95.

Ovesná, J., Ladislav Kucera, L., Hornícková, J., Svobodová, L., Stavelíková, H., Velísek, J. and Milella, L. 2011. Diversity of S-alk(en)yl cysteine sulphoxide content within a collection of garlic (Allium sativum L.) and its association with the morphological and genetic background assessed by AFLP. Scientia Horticulturae. 129: 541-547.

Panse, V. G. and Sukhatme, P. V. 1967. Statistical Methods for Agricultural Workers. ICRA Pub, New Delhi. pp. 152-165.

Patel, Z., Bhalerao, P.P., Gaikwad, S.S. and Sachin, A.J. 2017. Effect of foliar application of chemicals on growth and yield of garlic (Allium sativum L.) var. GG-4. International Journal of Chemical studies. 5(4): 1035-1037.

Pooja Rani, Panghal, V.P.S., Rana, M.K. and Dushan, D.S. 2015. Response of garlic to foliar application of urea and micronutrients. International Journal of Tropical Agriculture. 33(4): 2845-2849.

Premsekhar, M. and Rajshree, V. 2009. Performance of Hybrid Tomato as Influenced by Foliar Feeding of Water
Soluble Fertilizers. American-Eurasian Journal of Sustainable Agriculture. 3(1): 33-36.

Shaheen, A.M., Mona, M.A., Aisha, H., Ali, A.R. and Fatima, A.R. 2007. Natural and chemical phosphorus fertilizers as affected onion plant growth, bulb yield and its some physical and chemical properties. Australian Journal of Basic and Applied Sciences. 1(4): 519-524.

Shankar, P.C., Tripathi, M.D., Quereshi, A.A. and Lawande, K.E. 2002. Effect of organic seawed extract on growth, yield and quality of onion (Alliuium cepa L.) var. N-2-4-1. Journal of South Indian horticulture. 49(Special): 247-248.

Shanu, Naruka, I.S., Singh, P.P., Shaktawat, R.P.S. and Verma, K.S. 2013. Effect of seed treatment and foliar spray of thiourea on growth, yield and quality of coriander (Coriandrum sativum L.) under different irrigation levels. International Journal of Seed Spices. 3(1): 20-25.

Sharma, R., Tsuchiya, M. and Bartlett, J.D. 2008. Fluoride induces endoplasmic reticulum stress and inhibits protein synthesis and secretion. Environ Health Perspect. 116(9): 1142-1146.

Singh, V. and Pandey, M. 2006. Effect of integrated nutrient management on yield and Nutrient uptake by onion and on soil fertility. Journal of Indian Society of Soil Science. 54(3): 365-367.

Sterling, S.J. and Eagling, R.D. 2001. Agronomic and allicin yield of Australian grown garlic (Allium sativum). Acta Horticulture. 555: 63-73.

Talware, P., S. Dubay, S., Gupta, N.K. and Jain, P.K. 2010. Effect of organic, inorganic and biofertilizers on the growth and productivity of garlic (Allium sativum L.) CV. G-223. National Symposium on Alliums. Current Scenario and Emerging Trends. pp.18. 
Waghachavare, D.D. 2004. Effect of integrated nutrient management on growth, yield and quality of onion cv. Phule Suvarna. M.Sc. (Agri.) Thesis (Unpub.), Maharashtra Agricultural University, Parbhani.

Warade, A.D. 2004. Integrated weed management in onion. Ph. D. Thesis (Unpub.) Dr. Panjabrao Deshmukh Krishi Vidyapeeth, Akola.
Review of Analytical Methods. Garlic World. Available at: www.garlicworld.co.uk. Accessed August 28 ${ }^{\text {th }}, 2017$.

Yildirim, E., Guvenc, C., Turan, M. and Karatas, A. 2007. Effect of foliar urea application on quality, growth, mineral uptake and yield of broccoli (Brassica oleraceae L., var. Italica). Plant Soil and Environment. 53(3): 120-128.

Watson, M. 2005. The Chemistry of Garlic: A

\section{How to cite this article:}

Mehta, V.S., B.V. Padhiar and Vikas Kumar. 2017. Influence of Foliar Application of Water Soluble Fertilizers on Growth, Yield and Quality Attributes of Garlic (Allium sativum L.) var. Gujarat Garlic-3 in Southern Gujarat (India). Int.J.Curr.Microbiol.App.Sci. 6(10): 3211-3225. doi: https://doi.org/10.20546/ijcmas.2017.610.376 